\title{
Perspectives of Students on Acceptance of Tablets and Self- directed Learning with Technology
}

\author{
Sahin Gokcearslan \\ Gazi University, Turkey
}

\begin{abstract}
Recent mobile learning technologies offer the opportunity for students to take charge of the learning process both inside and outside the classroom. One of these tools is the tablet PC (hereafter 'tablet'). In parallel with increased access to e-content, the role of tablets in learning has recently begun to be examined. This study aims to reveal the relationship between the level of acceptance of tablets (TAM) and the level of selfdirected learning with technology (SDLT) of students and to differentiate these in terms of gender. A mixed method research design is used in this study. In addition, the qualitative part of the study aims to determine the reasons students have for using or not using tablets for supporting learning. The study group consisted of 414 high school students, involved in the pilot application group of the FATIH project in Turkey. According to the study, a significant positive relationship was determined between four of the variables of tablet acceptance and the SDLT level. While the degree of acceptance of tablets was different according to gender, the SDLT level was not.
\end{abstract}

Keywords: Tablet computers; Self-directed learning; Secondary education; Learning with technology; Gender studies

\section{Introduction}

Although tablets first emerged at the end of the 1980s, the first types were not widely adopted because of issues with operating systems, low computer processing speeds, internet connection problems, constraints in other characteristics and their size and weight (Atkinson, 2008; Gerpott, Thomas, \& Weichert, 2013). In recent years, tablets have offered increasingly tempting opportunities to users in industries such as health, construction and education due to their portability, ease-of-use and other features (El-Gayar, Moran, \& Hawkes, 2011). Tablets have provided an opportunity for students to be at the forefront of learning with their introduction into schools. They can provide access to the internet to both retrieve information and contribute to its production, and allow students to use tools such as simulations, wikis and blogs (Moran, Hawkes, \& El Gayar, 2010). Mobile technologies such as tablets and smartphones provide new modes and forms of interactions through social networking and an increased possibility of sharing information (Zhong, 2013). Tablets, which strongly aid this kind of interaction and information-sharing, can enhance the possibilities of learning within specific educational environments. Tablets can be used for many activities that support learning and the acquisition of knowledge, including taking notes during the lesson (Steinweg, Williams, \& Stapleton, 2010), accessing e-books (Dundar \& Akcayir, 2014), using different applications (Keskin \& Kuzu, 2015), using computer-aided test instruments (Siozos, Palaigeorgiou, Triantafyllakos, \& Despotakis, 2009) and carrying out research through various websites. 
In research into state-funded investments in 11 countries, primarily with regard to K12, Turkey was in overall first place with regard to the number of tablets that had been provided to students and for the size of the country's investment in this area (Tamim, Borokhovski, Pickup, \& Bernard, 2015). Within its FATIH (The Movement to Increase Opportunities and Technology) project, Turkey distributed 1437800 tablets to K12 students up till December 2015. There are plans to distribute 10600000 more tablets more from 2016 to 2019 and to provide in-service training for 900000 teachers on lesson contents (Cakmakci, 2015). In addition, more than 11 million students are registered on the Education Informatics Network (EBA), which contains more than 80000 learning resources made up of e-books, an e-portal, videos and audio files (EBA, 2016). E-contents thus occupy an important position in terms of providing self-learning opportunities to students.

While the use of computers in the classroom is becoming widespread and investments in this area are increasing, studies on computerization and educational outputs are limited (Bebell \& O'Dwyer, 2010). It has been suggested that further research is required to assess tablets' effectiveness in learning environments (Nguyen, Barton, \& Nguyen, 2015). Moreover, the degree of acceptance of a technology tends to indicate someone's intention to use it in the present, as well as their belief in its future potential usefulness (Smarkola, 2011). Whether or not mobile learning tools such as tablets are accepted and adopted is an important variable with regards to their use for effective learning in or outside of the classroom.

While learning occurs with tablets in the classroom environment, the learning process also continues outside the classroom. As a result of the rapidly increasing availability of and access to information today it has become difficult to view learning and information-gathering as something confined solely to the classroom environment. It has been suggested that students will increasingly acquire the skills needed in the current transition from mass education to individualized learning by using hand-held computers and smartphones (Corlett, Sharples, Bull, \& Chan, 2005).

One of these skills is self-directed learning. Self-directed learners are proactive learners who can take the initiative instead of waiting quiescently (Knowles, 1975). Individuals can acquire advanced cognitive behaviors with mobile self-directed learning skills (Sha, Looi, Chen, Seow, \& Wong, 2012). Alongside the level of self-directed learning one of the important variables is technology-aided learning (Holt, 2011; Jung, 2014; Kim, Olfman, Ryan \& Eryilmaz, 2014; Lee, Tsai, Chai \& Koh, 2014; Shum \& Tian, 2014). It has also been stated that the level of self-directed learning is a predictor for the integration of technology (Kirk, 2012). Self-directed learning is among the most important variables for mobile learning environments (Jung, 2014). There has not to date been any research in the literature assessing the relationship between the level of acceptance of tablets and the level of self-directed learning with technology. Gender has also been found to be among the variables that have an effect on the acceptance of technology (Yucel \& Gulbahar, 2013), and it has been suggested that studies be conducted on the acceptance of tablets relating to gender (Gungoren, Bektas, Ozturk, \& Horzum, 2014).

This study aims to contribute to the field in terms of self-directed learning with tablets by seeking an answer to the questions such as the relationship between SDLT and the acceptance of tablets that have an important potential in terms of in-class and non-class learning, the differentiation of the variables in terms of gender variable, intended use of the tablet computers and why they are not used for learning. 


\section{Literature Review}

\section{Acceptance of Tablets}

Understanding the acceptance of technology involves examining the cognitive and psychological aspects required for this acceptance to occur. It can be looked at by the use of a model which tries to explain factors that are effective for technology to be accepted and adopted (Gungoren et al., 2014). Various models for examining the acceptance of technology have been proposed and a number of them are found in various studies regarding the acceptance of tablets. In research on the acceptance of tablets, TAM (Cuhadar, 2014), the Unified Theory of Acceptance and Use of Technology (UTAUT) (Ifenthaler \& Schweinbenz, 2013), modified UTAUT (El-Gayar \& Moran, 2007; Moran et al., 2010), and the Theory of Planned Behavior (TPB) (Courtois, Montrieux, De Grove, Raes, De Marez \& Schellens, 2014) are the models that we encountered. The 'Technology Acceptance Model (TAM)' aims to measure people's intentions towards and beliefs involving the use of technology (Smarkola, 2011). TAM was the model most commonly selected as a baseline for the theoretical framework in studies examining international research on the expansion, acceptance and adoption of innovations in educational fields (Kaya \& Kocak Usluel, 2012; Usluel \& Mazman, 2010). Moreover, according to the results of content analysis of international publications, perceived benefit and ease of use are the variables most often studied (Usluel \& Mazman, 2010; Yucel \& Gulbahar, 2013).

TAM aims to explain the acceptance of technology by users by grounding itself on the perception of users (Davis, 1989). This model tries to predict behaviors within specific situations and uses Fishbein and Ajzen's 'Theory of Reasoned Action' (1975) as a baseline. According to Fishbein and Ajzen, the attitude of the individual affects his/her intention to carry out a specific action and the determinants of how he/she acts. According to the TAM model, Perceived Ease of Use (PEU), has a causal effect on Perceived Usefulness (PU). PU and PEU affect the intention to use a given tool, and this intention affects usage behavior. Perceived Usefulness is defined as "the degree to which an individual believes that using a particular system would enhance his or her job performance." Perceived Ease of Use is defined as "the degree to which an individual believes that using a particular system would be free of physical and mental effort." (Davis, 1986, p.26). This model is shown in Figure 1.

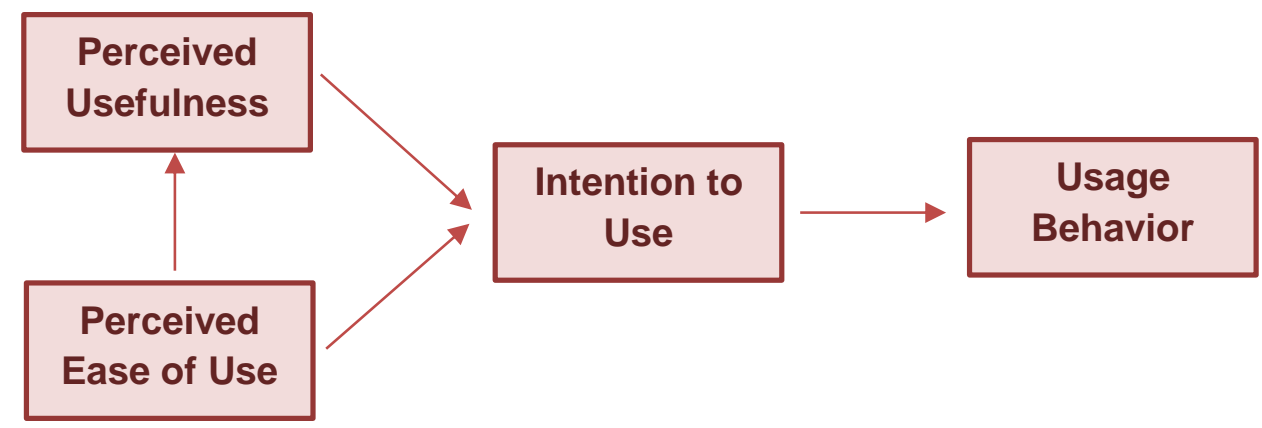

Figure 1. Technology Aceptance Model (Davis, 1986)

The TAM model has been adapted for studies on many different forms of technology and on the acceptance of learning systems using technology, such as learning management systems (Sánchez \& Hueros, 2010), e-learning (Park, 2009), e-portfolio systems (Shroff, Deneen, \& Ng, 
2011), mobile learning (Liaw \& Huang, 2011), mobile wireless networks (Kim, 2008), and the tablet (El-Gayar \& Moran, 2007).

\section{Self-directed Learning with Technology (SDLT)}

Self-directed learning (SDL) describes "a process by which individuals take the initiative, with or without the help of others, in diagnosing their learning needs, formulating learning goals, identifying human and material resources to help them in their learning, choosing and implementing appropriate learning strategies, and evaluating learning outcomes" (Knowles, 1975, p.18). Knowles, who thinks that the theory of andragogy, which came to light between the years 1970 and 1980 when the discussions about student-teacher centered learning approach were continuing for the learning of adults, can be carried to classroom environment, suggested that both of the approaches can be appropriate for children and adults depending on the situation (Merriam, 2001). SDL is a model that grounds on an integration that is about motivation, internal monitoring, and external management (Garrison, 1997). In addition to forming a basis for the implementation of modern learning approaches, SDL may also saves time and reduce expenditure (Alotaibi, 2015). According to the constructivist learning approach, the objective of education is to implement and achieve individual and self-directed learning (Chen, Kao, \& Sheu, 2003). It has been stated that there is a strong connection between SDL readiness and academic performance (Alotaibi, 2015).

At our present day, in which knowledge doubles itself in every 72 hours, SDL abilities have also started to become important with the technology having build-up its place stronger in the curriculum. When we think of cooperation in learning processes, personal liability for learning, self-confidence, persistence in learning and gumption, the help of digital tools have become non-negligible in the knowledge intensive 21st century age (Bryan, 2015). When we think that there will be access to a lot of and various education materials in the environments in which educational technology is used, learners have to be more active and they have to be more selfdirected learner (Akerlind \& Trevitt, 1999). In the literature, SDL and technology-aided learning are contextualized. Studies have been conducted on topics such as the place of SDL in the elearning environment (Kim, et al., 2014; Song \& Hill, 2007), language learning in the e-learning environment (Lai, Shum \& Tian, 2014), the opportunity provided for SDL by blogs (Robertson, 2011), the effect of technology on supporting SDL (Akerlind \& Trevitt, 1999; Lai, Shum, \& Tian, 2014; Lee et al., 2014; Su, Feng, Hsu \& Yang, 2013), SDL in planning an e-lesson (YamagataLynch, Do, Skutnik, Thompson, Stephens, \& Tays, 2015), and teaching design to increase SDL (Taminiau, Kester, Corbalan, Spector, Kirschner, \& van Merriënboer, 2015).

With regard to SDL it is important to ensure that students can access as many information sources as possible for their own learning needs and in accordance with their interests. Technological developments, which have provided the opportunity to access online information and expertise, may, in that sense, exert a direct influence on SDL (Timothy et al., 2010). In a study conducted with K12 teachers, it was concluded that students' readiness for SDL is a predictor of their ability to integrate technology (Kirk, 2012). It has also been stated that there is a relation between SDL and technology usage (Holt, 2011) and that there is a positive high level relationship between attitude towards computers and self-directed learning with technology (SDLT) (Demir, Yasar, Sert, Yurdugul, 2014). Gender also determines the degree of acceptance of technological devices. It has been suggested that gender is among the most important variables in the acceptance of tablets, and that research is needed in this area (Horzum, Ozturk, Bektas, Gungoren, \& Cakir, 2014). As mentioned above, the main objective of 
this study is to investigate the acceptance of tablets, and the correlation/differentiation of the variables involved. Within this context, the research questions given below were used alongside the aforementioned literature resources:

1) Do the levels of acceptance of tablets and the levels of SDLT differ according to gender?

2) Does the level of acceptance of tablets correlate with the level of SDLT?

3) What is the purpose of using tablets for students?

4) What are the student's views on not using tablets to assist them with lessons?

\section{Method}

\section{Research Model}

The quantitative method was used for the research questions on the acceptance of tablets and SDLT, and the qualitative method was used for in-depth analysis of the use of the tablets. Quantitative and qualitative data were used together in this mixed methods design study (Creswell, 2013).

\section{Study Group}

414 students participated in this study. They attended three different high schools in which the pilot scheme for the FATIH project had been conducted. Demographic information about the participants is given in Table 1. In addition, qualitative data was gathered from 214 of these students on a voluntary basis. The study was conducted during the spring semester of the 20142015 academic year. The schools were chosen from high schools in Ankara teaching students from the 9th to 11th grades. Three public high schools were selected using the convenience sampling method. These schools are located in the Cankaya district of the city of Ankara. This is the district whose level of education is the highest since Ankara is the capital city and Cankaya is the central district (TUIK, 2013). These three state high schools are placed near the top among the most successful schools of Turkey (Turkkamu, 2016).

Table 1. Demographic Attributes and the Level of Tablet Usage

\begin{tabular}{llll}
\hline Variable & & $\mathrm{N}$ & $\%$ \\
\hline Gender & Female & 243 & 58.7 \\
Grade & Male & 171 & 41.3 \\
& 9 & 85 & 20.5 \\
The level of Tablet usage* & 10 & 215 & 51.9 \\
& 11 & 114 & 27.6 \\
& 1 & 49 & 11.8 \\
& 2 & 24 & 5.8 \\
Total & 3 & 67 & 16.2 \\
\hline
\end{tabular}

*Tablet usage 1: Very bad, 2: Bad 3: Average, 4: Good 5: Very good 
When Table 1 is analyzed, it can be seen that more than half of the participants are female $(58.7 \%)$, and more than half of the participants are 10th grade students (51.9\%). The students' view was that their usage level is quite high. A small number of the students stated that they used a tablet and its applications less than the average level of Tablet usage (17.6\%).

From February 2013, tablets were given to student groups in schools where a pilot study was being conducted as one part of the FATIH project. Tablets were also distributed to teachers. The tablets belong to the students and the teachers, and they can use them anywhere they wish. Smartboards were also used in every classroom as part of the FATIH project. The tablets use the Android operating system, have a 7 inch screen, and have application that can open various documents. Tablets were distributed to students for access to all applications and e-learning contents within the EBA Applications Market such as e-books, videos, images, sounds, presentations, courses, exams, magazines, and news; software updating, failure tracking, mobile device management software is established for secure internet; tablet applications can be carried out with V-class implementation; virtual class applications can be carried out with smart board adaptation. Settings and galleries determined by the Ministry of National Education (MNE) were denied. To prevent inappropriate/hazardous usage, a Safe Internet Service was provided, meaning that access to some websites was denied (MNE, 2014).

\section{Data Collection Tools}

Data was collected through two scales and a qualitative data collection tool. To measure the acceptance of tablets, the Scale of Tablet PC Acceptance developed by Gungoren, Bektas and Horzum (2014), and the SDLT scale were used (Demir \& Yurdugul, 2013).

\section{The Scale of Tablet PC Acceptance}

The scale, which uses Davis's (1993) Technology Acceptance Model as a basis (Gungoren et al., 2014) consists of perceived ease of use, perceived benefit, attitude toward usage, and intention in using. Extent, appearance and structure validities are applied for the validity of the scale. Computers and instructional technologies, assessment and evaluation, development psychology and academicians from the field of Turkish language are selected to evaluate content and face validity. The assessment instrument contains 17 items and four factors after EFA analysis. As a result of the criterion validity measurements it is found out that the factors which constitute the scale are compatible and relevant. The variance ratio of the scale was $64.12 \%$. The internal consistency of the 5 point Likert scale was found to be .90. The internal consistency of this study was found to be .96 , which is very high. Confirmatory Factor Analysis (CFA- $\chi 2$ /sd=3.16, SRMR $=0.051, \mathrm{RMSEA}=0.074, \mathrm{AGFI}=0.87, \mathrm{GFI}=0.91, \mathrm{NFI}=0.96, \mathrm{NNFI}=0.97$ and $\mathrm{CFI}=0.97$ ) results showed an acceptable consistency for the scale.

\section{The Scale of Self-directed Learning with Technology (SDLT)}

The scale, which was originally developed by Teo, Tan, Lee, Chai and Koh (2010), evaluates young people's level of self-directed learning with technology. This is contrary to most self-directed learning scales, which are designed for use by adults. The assessment scale was translated into Turkish by Demir and Yurdugul (2013). The scale is subjected to transformation according to 4 
fields and the opinions of 4 linguists. Discriminant and convergent (AVE Value $>0.5$ ) validities are applied for construct validity. It is a 5 point Likert scale with 6 items in total, and a two-factor structure, and it explains $59.3 \%$ of the total variance. As a result of validation and credibility studies conducted with 1051 middle school and high school students in Turkey, the internal consistency level of the assessment instrument was found to be .73 . In this study, this level was found to be .87 which is quite high. The CFA results ( $\chi 2$ /sd=5.147, RMSEA=0.063, NFI=0.96, NNFI $0.96, \mathrm{CFI}=0.97, \mathrm{AGFI}=0.97$ ) showed acceptable consistency for the scale.

Qualitative data for the study was collected through two questions asked to students at the end of the scale:

1) For what purpose do you use your tablet?

2) If you do not use a tablet as to support your work in lessons, please indicate the reason why.

Qualitative and quantitative data for the study was collected together through one Google form.

\section{Findings}

The findings are presented in the order of the research questions. The Kolmogorov-Smirnov test was used to examine the research variables and it was seen that the scores did not show normal distribution $(p<0.05)$. Hence, non-parametric tests were used during the analysis.

\section{Findings Regarding Quantitative Data}

\section{The Acceptance of Tablets and the Change in SDLT Level According to Gender}

The analysis of the acceptance of tablets and the change in SDLT level according to gender is given in Table 2.

Table 2. Mann-Whitney U Test by Gender

\begin{tabular}{lcccccc}
\hline Gender & $\mathrm{N}$ & Variable & Mean & Total Points & $\mathrm{U}$ & $\mathrm{p}$ \\
\hline Female & 243 & PU & 189.40 & 46023.50 & 16377.5 & .00 \\
Male & 171 & & 233.23 & 39881.50 & & \\
Female & 243 & PEU & 193.25 & 46959.50 & 17313.5 & .003 \\
Male & 171 & & 227.75 & 38945.50 & & \\
Female & 243 & ATU & 196.70 & 47799.00 & 18153.0 & .026 \\
Male & 171 & & 222.84 & 38106.00 & & \\
Female & 243 & BIU & 196.85 & 47834.50 & 18158.5 & .028 \\
Male & 171 & & 222.63 & 38050.50 & & \\
Female & 243 & SDLT & 205.19 & 469860.50 & 20214.5 & 6.36 \\
Male & 171 & & 210.79 & 36044.50 & & \\
\hline
\end{tabular}

When the data presented in Table 2 was examined, it was seen that there is a meaningful difference between females and males in 4 variables regarding the acceptance of tablets. These are Perceived Usefulness (PU), Perceived Ease of Use (PEU), Attitude toward Using (ATU) and Behavioral Intention to Use (BIU), $(p<0.05)$. There is no meaningful difference between genders with regards to the SDLT level $(p>0.05)$ 


\section{The Level of Acceptance of Tablets and Its Relation with SDLT}

The results of Spearman correlation analysis, which was conducted to evaluate the relation between the level of acceptance of tablets and the level of SDLT. It was concluded that there is a positive meaningful relationship between the level of acceptance of tablets and SDLT levels (PU/SDLT=.70, PEU/SDLT=.73, ATU/SDLT=.67, BIU/SDLT=.71).

\section{Findings Regarding Qualitative Data}

Data about the intended usage of tablets are given in Table 3.

Table 3. Intended Usage of Tablets

\begin{tabular}{llll}
\hline Variable & & $\mathrm{n}$ & $\%$ \\
\hline Education & Assistance with lessons in general & 62 & 22.06 \\
& Researching information & 27 & 9.61 \\
& E-book & 25 & 8.90 \\
& E-content (video, audio) & 10 & 3.56 \\
& Learning a foreign language & 4 & 1.42 \\
\multirow{5}{*}{ Entertainment } & 3 & 1.07 \\
& Other & 73 & 25.98 \\
& Game & 25 & 8.90 \\
& Movie, music, TV series & 24 & 8.54 \\
& Social network & 24 & 8.54 \\
& General fun & 4 & 1.42 \\
& Surfing the Internet & 281 & 100 \\
\hline
\end{tabular}

When the data presented in Table 3 is examined, it can be seen that educational usage of tablet is at $46.62 \%$ and of use for entertainment is $53.38 \%$. Assistance with lessons in general (22.6\%), researching information for homework $(9.61 \%)$ and reading e-books $(8.9 \%)$ are the prominent subcategories within the education theme. Games (25.98\%), media (movies, music, TV series) $(8.9 \%)$, social networks $(8.54 \%)$ and general fun $(8.54 \%)$ are the prominent subcategories within entertainment.

Major reasons regarding why students do not use tablets to assist them with lessons are given in Table 4.

Among the reasons why students do not use their tablets to assist with lessons, the prominent reasons are not finding it useful $(23.13 \%)$, restrictions placed on applications and the internet (14.93\%), a preference for written resources instead of electronic ones $(11.94 \%)$, the distracting effect it has while studying $(10.45 \%)$, the inadequacy of e-content $(10.45 \%)$, disrupted/slow internet and battery problems (8.96\%). In addition, finding the tablet harmful to health $(5.2 \%)$ and finding it impractical (5.2\%) are also among the themes. The primary reason why students do not use tablets to assist with lessons is that students simply do not find their tablets useful. 
Tablets were distributed to students with limited applications and restrictions for Internet use and this is given as the second most important reason.

Table 4. The Reasons Why Students Do Not Use Tablets to Assist with Lessons

\begin{tabular}{lll}
\hline Variable & N & $\%$ \\
\hline Not useful & 31 & 23.13 \\
Restrictions placed on applications and the Internet & 20 & 14.93 \\
Preference for written resources & 16 & 11.94 \\
Distracting & 14 & 10.45 \\
Inadequacy of e-content & 14 & 10.45 \\
Disrupted/slow Internet & 12 & 8.96 \\
Not using during the lesson & 8 & 5.97 \\
Impractical & 7 & 5.22 \\
Negative effect on health & 7 & 5.22 \\
Battery problem & 5 & 3.73 \\
Total & 134 & 100 \\
\hline
\end{tabular}

\section{Discussion}

This study researched the level of acceptance of tablets and the level of SDLT in three schools being used to pilot the FATIH project. The relation among these two variables and differentiation according to gender constitute the quantitative part of the study. In the qualitative part one question was asked to learn about students' reasons for using their tablets and a second question was asked to discover any barriers against using them for educational purposes. According to the research results, there is a meaningful difference on behalf of male students for all the variables in the model for the level of acceptance of tablets. In one study conducted on the attitude of high school students towards tablets, a meaningful difference in terms of gender was not found (Dundar \& Akcayir, 2014). In another study, it was concluded that PEU and attitude variables regarding the acceptance of tablets are moderated by the gender variable (Hur, Kim, \& Kim, 2014). It has been stated that in situations that demand more effort in learning how to use technological devices, men have more of a tendency to make an effort (Venkatesh \& Morris, 2000). However, this problem can be overcome with user-friendly interfaces which require less effort (Hur et al., 2014). It has been suggested that in the acceptance of applicationbased mobile learning, there is no meaningful difference in terms of gender (Liaw \& Huang, 2015). In another study, it was stated that gender affects the intention to use and accept mobile technology for learning (Wang, Wu, \& Wang, 2009). However, although the level of SDLT is greater for male students, no meaningful difference was found in current study. In a study conducted with high school students, the level of self-directed learning of students who were learning Information and Communication Technologies (ICT) was found to be related to gender, and a meaningful difference was found to the disbenefit of male students (Asfar \& Zainuddin, 2015).

The level of acceptance of tablets and the SDLT level were found to be related. According to these results, PU, PUE, BIU are highly related, while ATU is moderately related to SDLT. Studies have been conducted on the effect of technology in supporting SDL (Akerlind \& Trevitt, 1999; Lai et al., 2014; Lee et al., 2014). While it has been shown that the level of readiness for SDL is 
an important determinant for technology integration (Kirk, 2012), it also has a strong relation to academic performance (Alotaibi, 2015). Self-directed learning, which is a prominent factor in adult education, has become an important variable for high school students in terms of the proliferation of technology and its position in young people's lives. Because of the rapid expansion and increased availability of information, using only lesson resources and the immediate classroom environment has become difficult. For learning environments in which technology opportunities are presented intensively such as within the FATIH project, studies should be conducted on how to increase the level of SDLT.

With regard to the intended usage of the tablets, the intention to use them for entertainment is slightly greater than for educational usage. Gong and Wallace (2012) also reached a similar conclusion. With regard to the educational usage of the tablets, assistance with lessons in general, researching information for homework and using them as an e-book are prominent. In a study conducted on attitudes towards tablets, there were factors that created a positive attitude towards tablets. These included the ideas that e-books ended the need to carry books around, that a tablet is both fun and practical, that it can help with homework, and that it increased students' interest in lessons (Dundar \& Akcayir, 2014). Students not only use tablets to access rich learning materials but also use it for researching information (Alyahya \& Gall, 2012). When it comes to leisure activities, using tablets for gaming is prominent, and media and social network usage follow this.

The reasons why students do not use tablets to assist with lessons are, in order: not finding them useful, the restrictions placed on applications and the internet, a preference for written resources instead of electronic ones, that they are distracting, the inadequacy of e-content, and technical problems. The first of these results, not finding them useful, is a variable which is about the acceptance of technology. Moreover, some of the students find tablets harmful to their health. In the study conducted by Dundar and Akcayir (2014), there were similar themes but with different rates, except for the preference for written materials. The Ministry of National Education places some filters on tablets for security reasons, and tablets are distributed for usage with some restrictions. Students want to access more lesson material (training videos, animation and e-books) with tablets, and they also want to use the internet freely (Dundar \& Akcayir, 2014). However, the MNE does provide thousands of pages of e-content for the use of students on EBA (EBA, 2016). The distracting effects of tablets when they are not being used for educational purposes were also mentioned (Kinash, Brand, \& Mathew, 2012; Wakefield \& Smith, 2012). Studies regarding the design of educational contents should be at the forefront of future work. For example, a recent study evaluates tablet applications when studying the problemsolving skills of 5 year old children (Falloon, 2013). In many studies conducted, students do find a tablet beneficial, but it is also suggested that policies should be put in place to help students adapt to learning with mobile technologies. These could involve subjects such as providing motivation, guidance, and technological support (Nguyen et al., 2015).

\section{Conclusion and Recommendations}

A meaningful difference in the level of acceptance of the tablet was found between male and female students. It is recommended that the software and hardware tools in tablet computers should be deeply investigated within the context of gender. There was no meaningful difference found in the level of SDLT in terms of the variable of gender, which indicates a positive state of affairs. The SDLT level is a variable that affects academic success and technology integration. The level of SDLT was found to be related to the level of acceptance of tablets. Increasing the 
level of acceptance of Tablet PCs will increase the level of SDLT. In future research, studies conducted on factors that affect both variables should provide significant findings with regards to mobile learning.

Tablets can be used for both education and entertainment/leisure activities. Their use for the latter can sometimes be seen as a form of relaxation, and sometimes be seen as a distraction from more important activities. Students can use tablets to assist with their lessons in general, research/search for information and read e-books. Tablets are also used as a support within the classroom environment, given with the opportunities they provide to access information. In this study, gaming was the most commonly mentioned intended usage for the students' tablets. This indicates a situation which does not necessarily seem positive. On the other hand, however, this result could however, be seen as an opportunity: It would be beneficial to design applications relating gaming to learning and to carry out further research to support these. Studies can be carried out in which the data can be acquired directly with the studies in which the computer logs are analyzed that are about which tools the students use more frequently while using tablet computers and for what purpose they use it.

When the reasons why students do not use their tablets to help them with their lessons were examined, not finding the tablets useful was the most prominent choice. Better lesson materials and activities which allow students to benefit from having tablets should be prepared. Teachers should use mobile technologies more effectively, and better motivate students to engage in out of classroom activities to support their SDLT. The restrictions that were placed on the internet and tablet applications should be reconsidered. The preference students expressed for written materials may be attributed to habit, or because e-books which take into account the specifics characteristics and needs of the students have not yet been designed. It is recommended that studies should be carried out in terms of instructional design in which the use of e-contents in tablet computers is evaluated. In addition to current deficiencies in e-content, the fact that tablets can be distracting is another obstacle against their usage as educational tools. However, technical problems such as battery problems were also indicated, although in the future, as the technology continues to develop, such problems are likely to become less and less of an issue.

\section{References}

Akerlind, G. S. \& Trevitt, A. C. (1999). Enhancing self-directed learning through educational technology: When students resist the change. Innovations in Education and Training International, 36(2), 96-105.

Alotaibi, K. N. (2015). The learning environment as a mediating variable between self-directed learning readiness and academic performance of a sample of Saudi nursing and medical emergency students. Nurse Education Today, 36, 249-254. doi:10.1080/1355800990360202

Alyahya, S. \& Gall, J. E. (2012, June). iPads in education: a qualitative study of students' attitudes and experiences. In World Conference on Educational Multimedia, Hypermedia and Telecommunications (Vol. 2012, No. 1, pp. 1266-1271). Retrieved on 1 December 2016 from https://www.learntechlib.org/p/40913.

Asfar, N., \& Zainuddin, Z. (2015). Secondary students' perceptions of information, communication and technology (ICT) use in promoting self directed learning in Malaysia. The Online Journal of Distance Education and E-Learning, 3(4), 67-82. 
Atkinson, P. (2008). A bitter pill to swallow: the rise and fall of the tablet computer. Design Issues, 24 (4), 3-25.

Bebell, D. \& O'Dwyer, L. M. (2010). Educational Outcomes and Research from 1: 1 Computing Settings. Journal of Technology, Learning, and Assessment, 9(1), n1.

Bryan, V. C. (2015). Self-directed learning and technology. The Education Digest, 80(6), 42-44.

Cakmakci, N. (2015). Fatih'e yeni yol haritası. Retrieved on 1 December 2016 http://www.hurriyet.com.tr/fatih-e-yeni-yol-haritasi-30268278

Chen, Y. S., Kao, T. C., \& Sheu, J. P. (2003). A mobile learning system for scaffolding bird watching learning. Journal of Computer Assisted Learning, 19(3), 347-359. doi:10.1046/j.0266-4909.2003.00036.x

Corlett, D., Sharples, M., Bull, S., \& Chan, T. (2005). Evaluation of a mobile learning organiser for university students. Journal of Computer Assisted Learning, 21(3), 162-170. doi: 10.1111/j.1365-2729.2005.00124.x

Courtois, C., Montrieux, H., De Grove, F., Raes, A., De Marez, L., \& Schellens, T. (2014). Student acceptance of tablet devices in secondary education: A three-wave longitudinal crosslagged case study. Computers in Human Behavior, 35, 278-286. doi: 10.1016/j.chb.2014. 03.017

Creswell, J. W. (2013). Nitel, nicel ve karma yontem yaklasimlari/arastirma deseni (Cev. ed. S. B. Demir). Ankara: Egiten Kitap.

Cuhadar, C. (2014). Information technologies pre-service teachers' acceptance of Tablet PCs as an innovative learning tool. Educational Sciences: Theory \& Practice, 14(2), 741-753. doi: 10.12738/estp.2014.2.2038

Davis F. D. (1986). A technology acceptance model for empirically testing new end-user information systems: Theory and results (Doctoral dissertation). Massachusetts Institute of Technology. Retrieved on 1 December 2016 from http://hdl.handle.net/1721.1/15192

Davis, F. D. (1989). Perceived usefulness, perceived ease of use, and user acceptance of information technology. MIS Quarterly, 13(3), 319-340. doi: 10.2307/249008

Davis, F. D. (1993). User acceptance of information technology: System characteristics, user perceptions and behavioral impacts. International Journal of Man-Machine Studies, 38(3), 475-487. Retrieved on 1 December 2016 from http://dx.doi.org/10.1006/imms. 1993.1022

Demir, A. G. O. \& Yurdugul, H. (2013). Self-directed learning with technology scale for young students: A validation study. E-international Journal of Educational Research, 4(3), 5873. Retrieved on 1 December 2016 from http://dergipark.ulakbim.gov.tr/ijer/article/ view/1073000316

Demir, O., Yasar, S., Sert, G., \& Yurdugul, H. (2014). Examination of the relationship between students' attitudes towards computer and self-directed learning with technology. Education \& Science, 39(176), 257-266. doi:10.15390/EB.2014.3621

Dundar, H. \& Akcayir, M. (2014). Implementing tablet PCs in schools: Students' attitudes and opinions. Computers in Human Behavior, 32, 40-46. doi:10.1016/j.chb.2013.11.020

EBA (2016). eba.gov.tr sosyal eğitim platformu istatistikleri. Retrieved on 1 December 2016 from http://www.eba.gov.tr 
El-Gayar, O. \& Moran, M. (2007). Evaluating students' acceptance and use of tablet PCs in collegiate classrooms. AMCIS 2007 Proceedings, 91. Retrieved on 1 December 2016 from https://pdfs.semanticscholar.org/004d/fc1fb031b1d9b63cf4e21e348dae9950dfad.pdf

El-Gayar, O., Moran, M., \& Hawkes, M. (2011). Students' Acceptance of Tablet PCs and Implications for Educational Institutions. Educational Technology \& Society, 14(2), 58-70.

Falloon, G. (2013). Young students using iPads: App design and content influences on their learning pathways. Computers \& Education, 68, 505-521. doi:10.1016/j.compedu.2013 .06 .006

Fishbein, M. \& Ajzen, I. (1975). Belief, attitude, Intention and behavior: An introduction to theory and research. Reading, MA: Addison-Wesley. Retrieved on 1 December 2016 from http://www.jstor.org/stable/40237022

Garrison, D. R. (1997). Self-directed learning: Toward a comprehensive model. Adult Education Quarterly, 48(1), 18-33.

Gerpott, T. J., Thomas, S., \& Weichert, M. (2013). Personal characteristics and mobile Internet use intensity of consumers with computer-centric communication devices: An exploratory empirical study of iPad and laptop users in Germany. Telematics and Informatics, 30(2), 87-99. doi:10.1016/j.tele.2012.03.008

Gong, Z., \& Wallace, J. D. (2012). A comparative analysis of iPad and other M-learning technologies: exploring students' view of adoption, potentials, and challenges. Journal of Literacy and Technology, 13(1), 2-29.

Gungoren, O. C., Bektas, M., Ozturk, E., \& Horzum, M. B. (2014). Acceptence of TPC scalevalidity and reliability study. Education and Science, 39(176), 69-79.

doi:10.15390/EB.2014.3497

Holt, L. L. (2011). Self-direction and technology use among new workforce entrants (Unpublished doctoral dissertation). University of Tennessee. Retrieved on 1 December 2016 from http://trace.tennessee.edu/utk_graddiss/1191.

Horzum, M. B., Ozturk, E., Bektas, M., Gungoren, O. C., \& Cakir, O. (2014). Secondary school students tablet computer acceptance and readiness: A structural equation modelling. Education \& Science, 39(176), 81-93. doi:10.15390/EB.2014.3500

Hur, W. M., Kim, H., \& Kim, W. M. (2014). The moderating roles of gender and age in tablet computer adoption. Cyberpsychology, Behavior, and Social Networking, 17(1), 33-39. doi: 10.1089/cyber.2012.0435

Ifenthaler, D. \& Schweinbenz, V. (2013). The acceptance of Tablet-PCs in classroom instruction: The teachers' perspectives. Computers in Human Behavior, 29(3), 525-534. doi:10.1016/j.chb.2012.11.004.

Jung, H. J. (2014). Ubiquitous learning: Determinants impacting learners' satisfaction and performance with smartphones. Language Learning \& Technology, 18(3), 97-119. doi:10.1016/j.chb.2012.11.004

Kaya, G. \& Kocak Usluel, Y. (2012). Ogrenme-ogretme sureclerinde BIT entegrasyonunu etkileyen faktorlere yonelik icerik analizi. Buca Egitim Fakultesi Dergisi, 31, 48-67.

Keskin, N. O. \& Kuzu, A. (2015). Development and testing of a m-learning system for the professional development of academics through design-based action research. The International Review of Research in Open and Distributed Learning, 16(1), 193-220. 
Kim, R., Olfman, L., Ryan, T., \& Eryilmaz, E. (2014). Leveraging a personalized system to improve self-directed learning in online educational environments. Computers \& Education, 70, 150-160. doi:10.1016/j.compedu.2013.08.006

Kim, S. H. (2008). Moderating effects of job relevance and experience on mobile wireless technology acceptance: Adoption of a smartphone by individuals. Information \& Management, 45(6), 387-393. doi:10.1016/j.compedu.2013.08.006

Kinash, S., Brand, J. \& Mathew, T. (2012). Challenging mobile learning discourse through research: student perceptions of Blackboard Mobile Learn and iPads. Australasian Journal of Educational Technology, 28, 4, 639-655.

Kirk, J. M. (2012). Self-directed learning: A potential predictor for technology integration among K-12 teachers (Unpublished doctoral dissertation). University of Tennessee. Retrieved on 1 December 2016 from http://trace.tennessee.edu/utk_graddiss/1534

Knowles, M. (1975). Self directed learning. Oxford, England: Gulf Publishing.

Lai, C., Shum, M., \& Tian, Y. (2014). Enhancing learners' self-directed use of technology for language learning: the effectiveness of an online training platform. Computer Assisted Language Learning, (ahead-of-print), 1-21. doi: 10.1080/09588221.2014.889714

Lee, K., Tsai, P. S., Chai, C. S., \& Koh, J. H. L. (2014). Students' perceptions of self-directed learning and collaborative learning with and without technology. Journal of Computer Assisted Learning, 30(5), 425-437. doi: 10.1111/jcal.12055

Liaw, S. S. L. \& Huang, H. M. (2011). Exploring learners' acceptance toward mobile learning. T. Teo (Ed.), Technology acceptance in education: Research and issues (ss. 145-157). Boston: Sense Publishers. doi:10.1007/978-94-6091-487-4_8

Liaw, S. S. \& Huang, H. M. (2015). How factors of personal attitudes and learning environments affect gender difference toward mobile learning acceptance. The International Review of Research in Open and Distributed Learning, 16(4), 104-132.

Loyens, S., Magda, J., \& Rikers, R. (2008). Self-directed learning in problem-based learning and its relationships with self-regulated learning. Educational Psychology Review, 20(4), 411427. doi:10.1007/s10648-008-9082-7.

Merriam, S. B. (2001). Andragogy and self-directed learning: Pillars of adult learning theory. New Directions for Adult and Continuing Education, 2001(89), 3-14.

MNE (2014). Frequently asked questions. Retrieved on 1 December 2016 from http://fatihprojesi.meb.gov.tr/tr/ssstablet.php

Moran, M., Hawkes, M., \& El Gayar, O. (2010). Tablet personal computer integration in higher education: Applying the unified theory of acceptance and use technology model to understand supporting factors. Journal of Educational Computing Research, 42(1), 79101. doi:10.2190/EC.42.1.d

Nguyen, L., Barton, S. M., \& Nguyen, L. T. (2015). Ipads in higher education-hype and hope. British Journal of Educational Technology, 46(1), 190-203. doi: 10.1111/bjet.12137

Park, S. Y. (2009). An analysis of the technology acceptance model in understanding university students' behavioral intention to use e-learning. Journal of Educational Technology \& Society, 12(3), 150-162. Retrieved on 1 December 2016 from http://www.jstor.org/ stable/jeductechsoci.12.3.150 
Robertson, J. (2011). The educational affordances of blogs for self-directed learning. Computers \& Education, 57(2), 1628-1644. doi:10.1016/j.compedu.2011. 03.003

Sánchez, R. A. \& Hueros, A. D. (2010). Motivational factors that influence the acceptance of Moodle using TAM. Computers in Human Behavior, 26(6), 1632-1640. doi:10.1016/ j.chb.2010.06.011

Sha, L., Looi, K.C., Chen, W., Seow, P., \& Wong, H. L. (2012). Recognizing and measuring selfregulated learning in a mobile learning environment. Computers in Human Behavior, 28, 718-728. doi:10.1016/j.chb.2011.11.019

Shroff, R. H., Deneen, C. D., \& Ng, E. M. (2011). Analysis of the technology acceptance model in examining students' behavioural intention to use an e-portfolio system. Australasian Journal of Educational Technology, 27(4), 600-618.

Siozos, P., Palaigeorgiou, G., Triantafyllakos, G., \& Despotakis, T. (2009). Computer based testing using "digital ink": Participatory design of a tablet PC based assessment application for secondary education. Computers \& Education, 52(4), 811-819. doi:10.1016/j.compedu.2008.12.006

Smarkola, C. (2011). A mixed-methodological technology adoption study. In T. Teo (Ed.), Technology acceptance in education (pp. 9-41). Rotterdam: Sense Publishers. doi: 10.1007/978-94-6091-487-4_2

Song, L. \& Hill, J. R. (2007). A conceptual model for understanding self-directed learning in online environments. Journal of Interactive Online Learning,6(1), 27-42.

Steinweg, S. B., Williams, S. C., \& Stapleton, J. N. (2010). Faculty use of tablet PCs in teacher education and K-12 settings. TechTrends, 54(3), 54-61. doi:10.1016/j.chb.2011.11.019

Su, Y., Feng, L., Hsu, C. H., \& Yang, C. C. (2013). Technology as an activity system for selfdirected, expanding learning: An analysis based on activity theory. Procedia-Social and Behavioral Sciences, 106, 2575-2582. doi:10.1016/j.sbspro.2013.12.296

Tamim, R. M., Borokhovski, E., Pickup, D., \& Bernard, R. M. (2015). Large-scale, governmentsupported educational tablet initiatives. Retrieved on 1 December 2016 from http://oasis.col.org/bitstream/handle/11599/809/COL\%20Tablet\%20Initiatives.pdf?seq uence $=1 \&$ isAllowed $=y$

Taminiau, E.M.C., Kester, L., Corbalan, G., Spector, J.M., Kirschner, P. A., \& Van Merriënboer, J.J.G. (2015). Designing on-demand education for simultaneous development of domainspecific and self-directed learning skills. Journal of Computer Assisted Learning, 31, 405421. doi: $10.1111 /$ jcal.12076

Teo, T., Tan, S. C., Lee, C. B., Chai, C. S., \& Koh, J. H. L. (2010). The self-directed learning with technology scale (SDLTS) for young students: An initial development and validation. Computers \& Education, 55(4), 1764-1771. doi:10.1016/j.compedu.2010.08.001

Timothy, T., Chee, T. S., Beng, L. C., Sing, C. C., Ling, K. J. H., Li, C. W., \& Mun, C. H. (2010). The self-directed learning with technology scale (SDLTS) for young students: An initial development and validation. Computers \& Education, 55(4), 1764-1771. doi:10.1016/j. compedu.2010.08.001

TUIK (2013). Secilmis gostergelerle Ankara. Retrieved on 1 December 2016 from http://www.tuik.gov.tr/ilGostergeleri/iller/ANKARA.pdf 
Turkkamu (2016). A complete ordered list of Turkey's most successful high schools. Retrieved on 1 December 2016 from http://www.turkkamu.net/turkiyenin-en-basarili-liseleri-tamsirali-liste/8807/

Usluel, Y. K. \& Mazman, S. G. (2010). Elements that take part in the process of propagation, acceptance and adoption of innovations in education: A content analysis. Cukurova University Faculty of Education Journal, 39, 60-74. Retrieved from http://egitim.cu.edu. tr/efdergi

Venkatesh, V. \& Morris, M. G. (2000). Why don't men ever stop to ask for directions? Gender, social influence, and their role in technology acceptance and usage behavior. MIS Quarterly, 24(1), 115-139. Retrieved on 1 December 2016 from http://www.jstor.org/ stable/3250981

Wakefield, J. \& Smith, D. (2012). From Socrates to satellites: iPad learning in an undergraduate course. Creative Education, 3, 5, 643-648.

Wang, Y. S., Wu, M. C., \& Wang, H. Y. (2009). Investigating the determinants and age and gender differences in the acceptance of mobile learning. British Journal of Educational Technology, 40(1), 92-118. doi: 10.1111/j.1467-8535.2007.00809.x

Yamagata-Lynch, L. C., Do, J., Skutnik, A. L., Thompson, D. J., Stephens, A. F., \& Tays, C. A. (2015). Design lessons about participatory self-directed online learning in a graduatelevel instructional technology course. Open Learning: The Journal of Open, Distance and e-Learning, 30(2), 178-189. doi: 10.1080/02680513.2015.1071244

Yucel, U. A. \& Gulbahar, Y. (2013). Technology acceptance model: a review of the prior predictors. Ankara University, Journal of Faculty of Educational Sciences, 46(1), 89-109.

Zhong, B. (2013). From smartphones to iPad: Power users' disposition toward mobile media devices. Computers in Human Behavior, 29(4), 1742-1748.

doi:10.1016/j.chb.2013.02.016

Correspondence: Sahin Gokcearslan, Ph.D., Department of Informatics, Gazi University, Besevler, Ankara, Turkey 